\title{
Blockchain Technology Meets Traceability in Fruit Supply Chain Management: A Systematic Review
}

\author{
Resista Vikaliana* \\ Faculty of Technology Management and Business, Universiti Tun Hussein Onn Malaysia \\ e-mail: resistav31@gmail.com \\ Raja Zuraidah Raja Mohd Rasi \\ Faculty of Technology Management and Business, Universiti Tun Hussein Onn Malaysia \\ e-mail: rzuraida@uthm.edu.my \\ I Nyoman Pujawan \\ Department of Teknik Industri, Institut Teknologi Sepuluh November, Surabaya, Indonesia \\ e-mail: pujawan@gmail.com \\ Irwansyah \\ Department of Management, STIES Gasantara, Sukabumi, Indonesia \\ e-mail: irwansyah.supandi@gmail.com
}

\begin{abstract}
Fruits are easily damaged, therefore, a tracing system is needed to ensure the commodity is well received by consumers. This study is a systematic review aims to identify areas where the fruits traceability provides the most value for supply chain management and to develop elements of a future research agenda for the fruits traceability in supply chain management. PRISMA or Preferred Reporting Items for Systematic Reviews and Meta-Analyses is used to help the systematic literature review. The result showed thad there are several values in applying traceability to the fruit supply chain, such as traceability guarantees the quality of fruit in the supply chain, traceability protects from fraud. Traceability will help increase consumer confidence in food safety, particularly on fruit. Blockchain technology is a promosing technology for a traceability system in industry and can be used successfully, by modifying the supply chain system and meeting the limitations first.
\end{abstract}

Keywords: Blockchain technology, traceability, fruit supply chain management, systematic review. 


\section{INTRODUCTION}

Fruits are easily damaged, therefore, a tracing system is needed to ensure the commodity is well received by consumers. Traceability of agricultural products is intended to present information on all or part of the supply chain of agricultural products ranging from harvesting, transportation, storage to distribution and sales that can guarantee the quality and safety of products distributed or consumed by consumers (Schiefer, 2008).

A traceability system must identify actors in the system, which will identify information as the most important requirement for developing an effective traceability system (Hu et al., 2013). In agriculture, a traceability system is needed to overcome several problems, for example the improper use of pesticides and fertilizers on fruits and vegetables which endanger human health. The implementation of traceability for food commodities has been carried out by Walmart. It conducts with the support of blockchain technology by IBM. Walmart has successfully carried out traceability on two commodities, namely porks in China and mangoes in the United States. Traceability carried out with blockchain technology, succeeded in tracing the origin of mangoes from 7 days to just 2.2 seconds and increased transparency (Kamath, 2018).

In addition, consumer attention to the quality of agricultural products has increased in recent years, which makes a traceability system more necessary (Mirabelli \& Solina, 2020). Traceability in the supply chain of an agricultural product is faced with technological challenges that can integrate the entire traceable data for the supply chain (Liu \& Gao, 2016).

In industry, blockchain has been emerged as a promising technology for a traceability system (Song et al., 2020). Blockchain is a technology that proposed to be a new model in tracing agricultural supply chains (Casado-Vara et al., 2018). So, at present, blockchain technology is a technology that can guarantee the tracking and tracing of agricultural supply chains. By implementing blockchain technology, the traceability and capacity to share information about production processes will be made easier and trustworthy. The objective of this review are: (1) Identify how the traceability provides the most value for fruits supply chain management (2) Identify how the use of blockchain technology could solve them.

\section{RESEARCH METHOD}

This study is a systematic literatur review, about fruit traceability. PRISMA or Preferred Reporting Items for Systematic Reviews and Meta-Analyses was conducted to help the systematic literature review. PRISMA is a published standard to conduct a systematic literature review.

The ATLAS.ti 7.0 software is used to help categorize and encode literature reviews. ATLAS.ti has the abbreviation Archiv fur Technik, Lebenswelt, Alltags Sprache (Archieve of Technology, Lifeworld and Everyday Language). ATLAS name prop up the idea as a map of the world and this described in document management meaningful. These software provides meaning of interpretation text (Friese, 2014).

\section{RESULT AND DISCUSSIONS}

\section{Result}

This study uses the main database, namely Scopus, because it is robust. However, no database is perfect or comprehensive, including Scopus. This study conducted searches on several well-established sources such as Science Direct, Proquest and Google Scholar, which are trusted databases, with searches in the areas of supply chain management, operations management, logistics or operations research.

A total of 241 articles were screened based on the inclusion and exclusion criteria defined by the researchers (Table 1). The first criterion was the literature type in which the researchers decided to focus only on research paper, review paper, conference proceeding as the primary sources. Hence, this further implies that other publication form were excluded in this research. In addition, the review only focused on articles that were published in English. The 2012-2020 
discussed traceability in the fruit supply chain using blockchain technology. The most important is all articles published in the field of social science, Supply Chain Management, Logistics, Operation Management, Research Operation, were selected in order to increase the possibility of retrieving related articles. Eventually a total of 10 remaining articles is ready to be analyzed.

Table 1. Criterion, Inclusion and Exclusion of Fruit Traceability

\begin{tabular}{|c|c|c|}
\hline Criterion & Inclusion & Exclusion \\
\hline Types of literature & $\begin{array}{l}\text { Research paper, review paper, conference } \\
\text { proceeding }\end{array}$ & $\begin{array}{l}\text { Book series, book, chapter in book, } \\
\text { short communication }\end{array}$ \\
\hline Language & English & Non English \\
\hline Time line & Between 2012 and 2020 & Before 2012 \\
\hline Subject Area & $\begin{array}{l}\text { Supply Chain Management, Logistics, } \\
\text { Operation Management, Research } \\
\text { Operation }\end{array}$ & $\begin{array}{l}\text { Other than Supply Chain } \\
\text { Management, Logistics, Operation } \\
\text { Management, Research Operation }\end{array}$ \\
\hline
\end{tabular}

Data Abstraction and Analysis

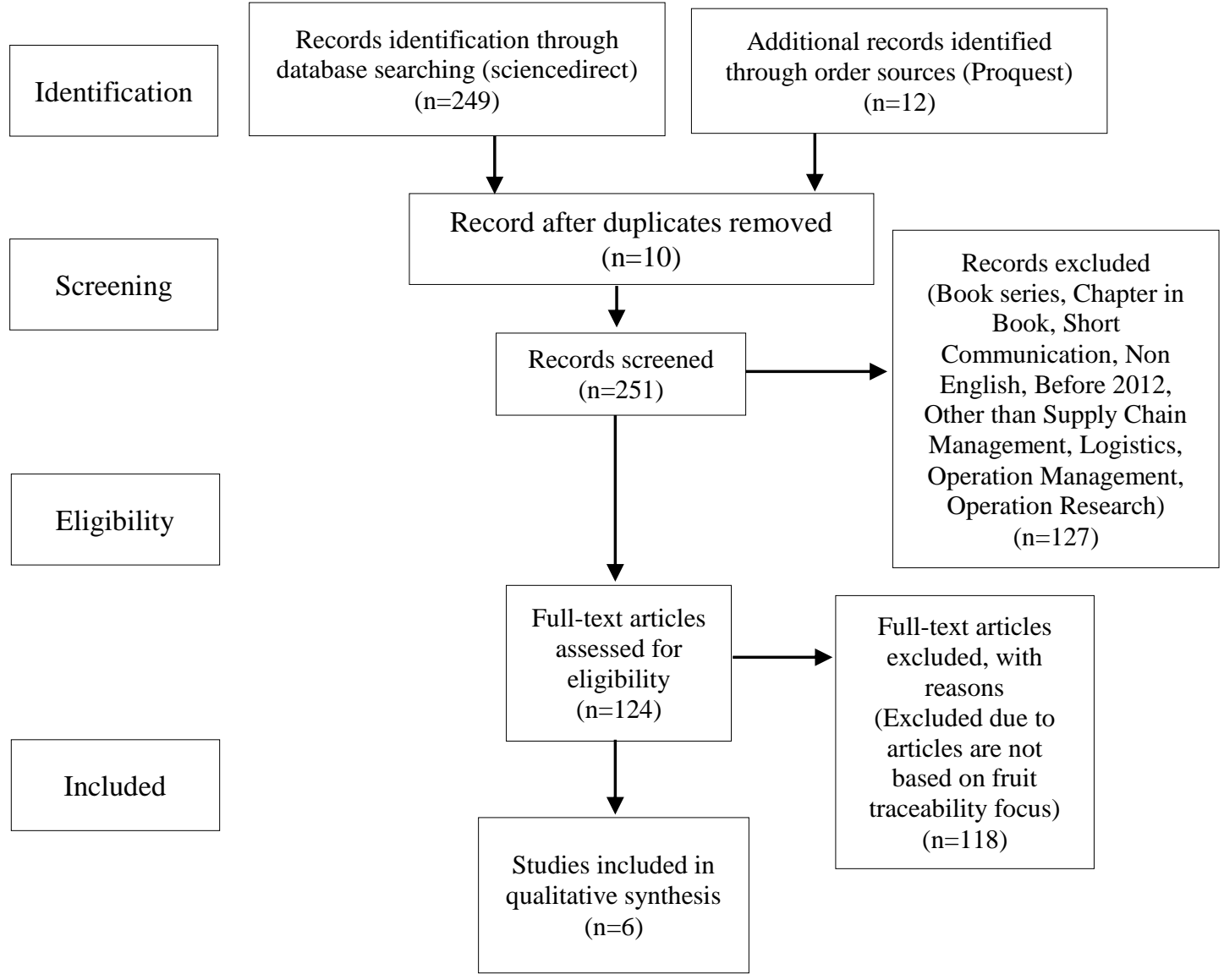

Figure 1. PRISMA of Fruit Traceability

Some codes applied at this stage are technology in traceability in agricultural supply chain, traceability in consumer's perspective, traceability in tools analysis, and fruit traceability. A summary of the design and characteristics of the 6 studies (refer to Figure 2.1. above) included in the systematic review with excluded due to articles are not based on focus on fruit traceability (114 articles). This Table 2 below is a summary of the review of fruit traceability based on systematic literature review. 
Table 2. A Summary of Fruit Traceability Review

\begin{tabular}{|c|c|c|c|}
\hline Author & Year & Source Type & Application Area \\
\hline $\begin{array}{l}\text { Rolando Saltini, Renzo } \\
\text { Akkerman, Stina Frosch }\end{array}$ & 2013 & Journal & Cocoa Traceability \\
\hline $\begin{array}{l}\text { Normansyah Syahruddin, } \\
\text { Matteo Kalchschmidt }\end{array}$ & 2013 & Journal & Cocoa traceability in Indonesia \\
\hline $\begin{array}{l}\text { Iwan Vanany, Kuntoro Boga } \\
\text { Andri, Ronny Mardiyanto, } \\
\text { Niniek Fajar Puspita and } \\
\text { Wiwik Heny Winarsih, Andri } \\
\text { \& Per Engelseth }\end{array}$ & 2015 & Journal & $\begin{array}{l}\text { Electronic traceability system of } \\
\text { fresh fruit supply chain in } \\
\text { Indonesia }\end{array}$ \\
\hline $\begin{array}{l}\text { Iwan Vanany, Ronny } \\
\text { Mardiyanto, Royyana Muslim } \\
\text { Ijtihadie, Kuntoro Boga Andri } \\
\text { \& Per Engelesth }\end{array}$ & 2016 & Journal & $\begin{array}{l}\text { Mango traceability in Indonesia } \\
\text { using electronic system }\end{array}$ \\
\hline $\begin{array}{l}\text { Giovanni Mmirabelli, Vittorio } \\
\text { Solina }\end{array}$ & 2020 & $\begin{array}{l}\text { Conference } \\
\text { Proceeding }\end{array}$ & $\begin{array}{l}\text { Agricultural supply chains } \\
\text { traceability using blockchain } \\
\text { technology }\end{array}$ \\
\hline $\begin{array}{l}\text { Luisa Palmieri, Elisa Bozza } \\
\text { Lara Giongo }\end{array}$ & 2009 & Journal & $\begin{array}{l}\text { Soft fruit (strawberries; } \\
\text { blueberries; currant, raspberry, } \\
\text { orange. }\end{array}$ \\
\hline
\end{tabular}

\section{Discussions}

In agribusiness commodity context, the application of the blockchain technology is still in its early stage. Particularly about fruit traceability issues, very few papers are present in the literature.

This following discussion show (1) the traceability provides the most value for fruits supply chain management (2) how the use of blockchain technology could solve them.

RO1. To identify areas where the traceability provides the most value for fruits supply chain management. The following are some of the values of the traceability process in fruit supply chain management: (Palmieri et al., 2009; Saltini et al., 2013; Vanany et al., 2016)(Mirabelli \& Solina, 2020; Syahruddin \& Kalchschmidt, 2012; Vanany et al., 2015)

1. Traceability guarantees the quality of fruit in the supply chain, besides traceability can authenticate and identify products in order to protect consumers.

2. Traceability protects the food industry, from farmers, distributors and consumers from fraud or fraud, with more specific and accurate measurements.

3. In agriculture, the search for a reliable system in the supply chain for agricultural commodities is needed to reduce problems or shortages such as providing pesticides that are harmful to human health.

4. Traceability will help increase consumer confidence in food safety

5. To identify what is wrong in a company's supply chain, a good tracing system is needed that is able to reveal the problems that occur along the chain

6. Blockchain technology can help provide solutions to these problems by overcoming the challenges of visibility and traceability.

RO2 To develop elements of a future research agenda for the fruit traceability within the supply chain. The following is a table that shows a summary of the problem of traceability in the fruit supply chain and how blockchain technology contributes to solving these problems (Table $3)$. 


\begin{tabular}{|c|c|}
\hline The Problems & Blockchain Contribution to Solve The Problems \\
\hline $\begin{array}{l}\text { Two-way traceability: distribution of } \\
\text { perishable products and transportation and } \\
\text { detection of on-farm processes, for example } \\
\text { the use of pesticides (Aiello et al., 2015; } \\
\text { Paciarotti \& Torregiani, 2021). }\end{array}$ & $\begin{array}{l}\text { Blockchain technology promises a system that is } \\
\text { transparent, resistant, damaged and safe(Casino et al., } \\
\text { 2019) }\end{array}$ \\
\hline $\begin{array}{l}\text { Source of traceability information (Aiello et } \\
\text { al., 2015; Folinas et al., 2006) }\end{array}$ & $\begin{array}{l}\text { Blockchain technology can safely store digital } \\
\text { transactions and distributed software mechanisms that } \\
\text { provide systems with a list of trusted asset } \\
\text { transactions, without requiring central trust authority } \\
\text { (A. Banerjee, 2018; M. Banerjee } \text { et al., 2018). }\end{array}$ \\
\hline $\begin{array}{l}\text { Regulations that emphasize product quality } \\
\text { assurance, which can force farmers to care } \\
\text { about the traceability of agricultural } \\
\text { products, especially fruit (Manning \& Soon, } \\
\text { 2013; Wei \& Huang, 2017). }\end{array}$ & $\begin{array}{l}\text { Blockchain technology can help provide solutions to } \\
\text { these problems by overcoming the challenges of } \\
\text { visibility and traceability (Alharby \& Moorsel, 2018): } \\
\text { a. Traceability will help increase consumer } \\
\text { confidence in food safety (Andoni et al., 2019). } \\
\text { b. To identify what is wrong in a company's supply } \\
\text { chain, a good tracing system is needed that is able } \\
\text { to reveal the problems that occur along the chain } \\
\text { (Angrish } \text { et al., 2018). }\end{array}$ \\
\hline $\begin{array}{l}\text { Farmers acceptance of adoption in the } \\
\text { traceability system, especially in regions or } \\
\text { countries where most producers market } \\
\text { their products independently. (Souza } \\
\text { Monteiro \& Caswell, 2009) }\end{array}$ & $\begin{array}{l}\text { Blockchain technology is considered as one of the main } \\
\text { techniques that are strong in security and privacy } \\
\text { domain (Galvez et al., 2018; Hirbli, 2018). }\end{array}$ \\
\hline $\begin{array}{l}\text { Traceability of the type of fruit used as raw } \\
\text { material for a product(Ab Rashid \& Bojei, } \\
\text { 2019; Liao et al., 2011) . } \\
\text { Actors in fruit supply chain management } \\
\text { develop traceability as an organized habit or } \\
\text { routine (Routroy \& Behera, 2017). }\end{array}$ & $\begin{array}{l}\text { Each block has a limit on how many transactions it } \\
\text { can have, so usually the actors prioritize transactions } \\
\text { by choosing the most profitable (A. Banerjee, 2018) } \\
\text { The blockchain structure manages all transactions in a } \\
\text { robust and auditable manner (A. Banerjee, 2018) }\end{array}$ \\
\hline
\end{tabular}

There is a linking of the fruit traceability to performances of the chains as a driver to reach sustainability. Developing an technology in a traceability system that is relatively supportive to help members of the supply chain to complete their traceability system capabilities. Organizing fruit traceability significantly involves the integration of different supply network actors as well as the time-limited integration of external actors with technical competence about the traceability system. Some fruit traces that have been clearly explored are mangoes, cocoa, strawberries; blueberries; currant; raspberry; orange; pineapple. Other studies only mention fresh fruit or more generally by mentioning an agricultural commodity.

Based on the references studied, in the agricultural sector, especially fruit traceability, there are almost no real case studies, so the benefits derived from the traceability process are unclear. In addition, it is necessary to deepen the tendency of potential stakeholders towards the adoption of this blockchain technology; substantially. Much effort is still needed in order to increase the credibility and reputation of blockchain technology.

\section{CONCLUSION}

The research gap based on fruit traceability as the main finding is there are several values in applying traceability to the fruit supply chain, such as traceability guarantees the quality of fruit in the supply chain, traceability protects from fraud. Traceability will help increase consumer confidence in food safety, particularly on fruit.

Blockchain technology appears to be very useful in traceability, which in the near future might be a valid means of minimizing fraud and errors in the fruit supply chain, thereby increasing quality and safety. The fruits that has implemented traceability are mangoes, cocoa, strawberries; 
blueberries; currant; raspberry; orange; pineapple. It means agribusiness commodity traceability research still has the potential to be studied.

Overall, the blockchain appears to be very useful in traceability, which in the near future might be a valid means of minimizing fraud and errors in the fruit supply chain, thereby increasing quality and safety.

\section{REFERENCES}

Ab Rashid, N., \& Bojei, J. (2019). The relationship between halal traceability system adoption and environmental factors on halal food supply chain integrity in Malaysia. Journal of Islamic Marketing, 11(1), 117-142. https://doi.org/10.1108/JIMA-01-2018-0016.

Aiello, G., Enea, M., \& Muriana, C. (2015). The expected value of the traceability information. European Journal of Operational Research, 244(1), 176-186. https://doi.org/10.1016/j.ejor.2015.01.028.

Alharby, M., \& Moorsel, A. Van. (2018). The Impact of Profit Uncertainty on Miner Decisions in Blockchain Systems. Electronic Notes in Theoretical Computer Science, 340, 151-167. https://doi.org/10.1016/j.entcs.2018.09.011.

Andoni, M., Robu, V., Flynn, D., Abram, S., Geach, D., Jenkins, D., Mccallum, P., \& Peacock, A. (2019). Blockchain technology in the energy sector: A systematic review of challenges and opportunities. Renewable and Sustainable Energy Reviews, 100(February 2018), 143 174. https://doi.org/10.1016/j.rser.2018.10.014.

Angrish, A., Craver, B., Hasan, M., \& Starly, B. (2018). A Case Study for Blockchain in Manufacturing: "fabRec": A Prototype for Peer-to-Peer Network of Manufacturing Nodes. Procedia Manufacturing, 26, 1180-1192. https://doi.org/10.1016/j.promfg.2018.07.154.

Banerjee, A. (2018). Blockchain Technology: Supply Chain Insights from ERP. In Advances in Computers (1st ed., Vol. 111). Elsevier Inc. https://doi.org/10.1016/bs.adcom.2018.03.007.

Banerjee, M., Lee, J., \& Choo, K. R. (2018). A blockchain future for internet of things security: a position paper. Digital Communications and Networks, 4(3), 149-160. https://doi.org/10.1016/j.dcan.2017.10.006.

Casado-Vara, R., Prieto, J., La Prieta, F. De, \& Corchado, J. M. (2018). How blockchain improves the supply chain: Case study alimentary supply chain. Procedia Computer Science, 134, 393-398. https://doi.org/10.1016/j.procs.2018.07.193.

Casino, F., Dasaklis, T. K., \& Patsakis, C. (2019). Telematics and Informatics A systematic literature review of blockchain-based applications : Current status, classification and open issues. Telematics and Informatics, 36(November 2018), 55-81. https://doi.org/10.1016/j.tele.2018.11.006.

Folinas, D., Manikas, I., \& Manos, B. (2006). Traceability data management for food chains. British Food Journal, 108(8), 622-633. https://doi.org/10.1108/00070700610682319.

Friese, S. (2014). Qualitative Data Analysis with ATLAS.ti (2nd Ed). SAGE Publication.

Galvez, J. F., Mejuto, J. C., \& Simal-Gandara, J. (2018). Future challenges on the use of blockchain for food traceability analysis. In TrAC - Trends in Analytical Chemistry. https://doi.org/10.1016/j.trac.2018.08.011.

Hirbli, T. (2018). Palm Oil traceability: Blockchain meets supply chain. Executive Summary, 138. https://dspace.mit.edu/bitstream/handle/1721.1/117800/1051223547MIT.pdf?sequence $=1$.

Hu, J., Zhang, X., Moga, L. M., \& Neculita, M. (2013). Modeling and implementation of the vegetable supply chain traceability system. Food Control, 30(1), 341-353. https://doi.org/10.1016/j.foodcont.2012.06.037.

Kamath, R. (2018). The Journal of The British Blockchain Association. The Journal of The British Blockchain Association, 1(1), 1-12.

Liao, P. A., Chang, H. H., \& Chang, C. Y. (2011). Why is the food traceability system unsuccessful in Taiwan? Empirical evidence from a national survey of fruit and vegetable farmers. Food Policy, 36(5), 685-692. https://doi.org/10.1016/j.foodpol.2011.06.010. 
Liu, Y.-C., \& Gao, H.-M. (2016). An Empirical Study for the Mobile Food Trace ability: Private Trace ability System for the White Gourd in Tianjin, China. ITM Web of Conferences, 7, 01006. https://doi.org/10.1051/itmconf/20160701006.

Manning, L., \& Soon, J. M. (2013). GAP framework for fresh produce supply. British Food Journal, 115(6), 796-820. https://doi.org/10.1108/BFJ-Sep-2011-0236.

Mirabelli, G., \& Solina, V. (2020). Blockchain and agricultural supply chains traceability: research trends and future challenges. Procedia Manufacturing, 42(2019), 414-421. https://doi.org/10.1016/j.promfg.2020.02.054.

Paciarotti, C., \& Torregiani, F. (2021). The logistics of the short food supply chain: A literature review. Sustainable Production and Consumption, 26, 428-442. https://doi.org/10.1016/j.spc.2020.10.002.

Palmieri, L., Bozza, E., \& Giongo, L. (2009). Soft Fruit traceability in food matrices using RealTime PCR. Nutrients, 1(2), 316-328. https://doi.org/10.3390/nu1020316

Routroy, S., \& Behera, A. (2017). Agriculture supply chain. 7(3), 275-302. https://doi.org/10.1108/JADEE-06-2016-0039.

Saltini, R., Akkerman, R., \& Frosch, S. (2013). Optimizing chocolate production through traceability: A review of the influence of farming practices on cocoa bean quality. Food Control, 29(1), 167-187. https://doi.org/10.1016/j.foodcont.2012.05.054.

Schiefer, G. (2008). Tracking and Tracing - A Challenge for System Organozatioon and IT. Journal of Information Technology in Agriculture , 3, 19-25.

Song, J. M., Sung, J., \& Park, T. (2020). Applications of Blockchain to Improve Supply Chain Traceability. Procedia Computer Science, 162(Itqm 2019), 119-122. https://doi.org/10.1016/j.procs.2019.11.266.

Souza Monteiro, D. M., \& Caswell, J. A. (2009). Traceability adoption at the farm level: An empirical analysis of the Portuguese pear industry. Food Policy, 34(1), 94-101. https://doi.org/10.1016/j.foodpol.2008.07.003.

Syahruddin, N., \& Kalchschmidt, M. (2012). Traceability in the Cocoa Supply Chain: An Indonesian Context. 23rd Annual Conference of the Production and Operations Management Society, 1-17. https://doi.org/10.1111/j.1365-2621.2011.02578.

Vanany, I., Andri, K. B., Mardiyanto, R., Puspita, N. F., \& Winarsih, W. H. (2015). An Electronic Traceability System for an Indonesian Fresh Fruit Supply Chain. IPTEK Journal of Proceedings Series, O(1), 4-7. https://doi.org/10.12962/j23546026.y2014i1.297.

Vanany, I., Mardiyanto, R., Ijtihadie, R. M., \& Boga, K. (2016). Developing electronic mango traceability in Indonesia. https://doi.org/10.1080/16258312.2016.1143206.

Wei, Y. P., \& Huang, S. H. (2017). Food traceability system as elevating good corporate social responsibility for fast-food restaurants. Cogent Business and Management, 4(1), 1-10. https://doi.org/10.1109/MWSYM.2018.8439177. 